\title{
Precision Ground Water Sampling in Coastal Aquifers Using a Direct-Push, Shielded-Screen Well-Point System
}

\author{
by Matthew A. Charette and Matt C. Allen
}

\section{Abstract}

Conventional ground water sampling methods are often expensive and lack the sampling resolution required to categorize geochemical processes in surficial aquifers. Here, we describe the application of a commercially available gas vapor sampling probe to ground water sampling in shallow coastal aquifers. The system involves a small-diameter, shielded-screen well-point sampler that can provide high resolution $(\sim 10 \mathrm{~cm})$ to depths of $10 \mathrm{~m}$ or greater depending on the aquifer matrix. Examples of the system's utility are presented for two geologically contrasting environments (Waquoit Bay, Massachusetts, USA; Ubatuba, Brazil). In Waquoit Bay, the sampler allowed us to resolve a sharp saline transition zone $(\sim 2 \mathrm{~m})$ and the associated changes in nutrients and trace metals that were associated with biogeochemical reactions at this interface. The system also proved useful in Ubatuba, Brazil, where small-scale gradients in sediment composition and permeability controlled the ground water salinity profile.

\section{Introduction}

Issues surrounding quality, availability, and protection of ground water have become increasingly important in recent decades with the pressure of expanding populations, especially in coastal areas. A major source of coastal pollution arrives via ground water, which can accumulate contaminants from waste water, agriculture, and atmospheric deposition (e.g., Johannes 1980; Valiela et al. 1992). Coastlines with sandy aquifers have beaches where fresh ground water mixes with salty ground water (Barlow 2003) in a zone recently termed the subterranean estuary, and the resulting changes in salinity and (usually) oxygen content lead to the potential for significant chemical transformations (Moore 1999; Charette and Sholkovitz 2002). Until recently, the subterranean estuary has received limited attention, mainly because it is difficult to sample.

A number of methods are available for sampling coastal ground water systems (Barcelona et al. 1983; Geoprobe Systems 2001; Puls and Paul 1997; Ronen et al. 1987; Schulmeister et al. 2004). More traditional methods, like the installation of monitoring wells through hand auguring, jetting, and drilling, are not only expensive but also very disruptive to the aquifer material. Pore water chemistries are significantly altered during installation and therefore accurate data cannot be collected immediately.
These methods also provide inadequate spatial detail for accurately characterizing geochemical processes within an aquifer, especially in coastal areas where chemical gradients are often sharp (Testa et al. 2002). While monitoring wells are well suited for single-depth data collection, an extensive network of wells would need to be installed in order to obtain a range of depths. This is often unfeasible due to the small budgets that are normally granted for basic research. In order to achieve two- and three-dimensional data sets, an expensive network of multilevel wells would need to be installed.

Using drive-point piezometers is an alternative method for obtaining ground water samples. The typical exposedscreen design has several limitations. Large diameters (1.125-inch diameter) can make it difficult to install without a technique that disrupts the aquifer (i.e., jetting) and long screened intervals ( $>12$ inches) that reduce the vertical sampling resolution. Data quality also comes into question if the materials used in constructing the piezometer represent a contamination source for the element or compound of interest (Schulmeister et al. 2004).

New well-point systems aim to solve the problems of conventional methods. To increase the depth of penetration, the diameter of well-point systems is critical. Nonreactive materials should also be used for all parts coming in contact with the water sample.

In this paper, we describe the application of a commercially available gas vapor sampling kit to ground water 
sampling in shallow coastal aquifers $\left(\mathrm{AMS}^{\mathrm{TM}}\right.$ Gas Vapor Probe System; http://www.ams-samplers.com; hereafter referred to as the "system"). In our tests, we have successfully driven this system to a depth of $10 \mathrm{~m}$ in a sandy coastal aquifer, with discrete samples collected at up to 10$\mathrm{cm}$ resolution. The sampling tip (AMS ${ }^{\mathrm{TM}}$ Retract-a-Tip; hereafter referred to as the "sampler") is constructed of high-grade stainless steel, and the extension rods are lined internally with Teflon ${ }^{\circledR}$ or nylon tubing to prevent trace metal or other contamination as the sample is pumped to the surface. The sampler eliminates screen blockage with fine materials during installation, a problem that is endemic to exposed-screen models. These problems have been overcome by similar shielded-screen samplers (Zemo et al. 1994, 1995), but most of these methods are limited to single-depth usage. Thus, the most important features of the sampler are its portability and that it can be used to sample multiple depths, limited only by sampling resolution, in a single profile. For example, a small transect of ground water profiles can resolve centimeter-scale chemical interfaces, or a network of transects could produce the boundary conditions (hydraulic head, conductivity) necessary for a high-resolution ground water model. The results of some typical profiles taken with the sampler, as well as a thorough description of field techniques, will follow.

\section{Materials and Procedures}

\section{Field Sites}

Ground water profiles presented in this paper were from two locations: Waquoit Bay, Massachusetts, and Ubatuba, Brazil. Waquoit Bay is located on the southwest coast of Cape Cod, Massachusetts. Considerable vertical contrasts in a number of chemical parameters had already been identified at this site (Cambareri and Eichner 1998; Charette and Sholkovitz 2002; Testa et al. 2002; Abraham et al. 2003; Talbot et al. 2003; Charette et al. 2005). Cape Cod is an end moraine deposit from the late Wisconsinan deglaciation of $\sim 12,000$ to 15,000 years ago (Oldale 1981). The sedimentary deposits of the study area generally consist of outwash gravel, sand, and silt, with occasional lacustrine deposits of silts and clays (Oldale 1976). Slug tests in this region of the aquifer have yielded hydraulic conductivities $(K)$ ranging from 0.12 to $50 \mathrm{~m} / \mathrm{d}$ (E.C. Jordan Inc. 1990). The aquifer is unconfined, $\sim 100$ to $120 \mathrm{~m}$ thick in the study area, and bounded by less permeable deposits of till and bedrock beneath (LeBlanc et al. 1986). The aquifer is also bounded by marine water at its margins. The aquifer at the head of Waquoit Bay has a well-defined subterranean estuary, where fresh ground water upwells over denser saline ground water beneath the beach face (Testa et al. 2002).

In contrast to Cape Cod, the coastline of Brazil near Ubatuba is characterized by fractured crystalline rocks, steep elevation gradients, and an annual rainfall of $1.8 \mathrm{~m}$ (Mahiques 1995). The fractured bedrock aquifers lead to occasionally large point source discharges of ground water (Oliveira et al. 2003). In the embayment where we collected our ground water profile (Flamengo Bay), the sediment profile consisted of very coarse sand above highly weathered bedrock.

\section{Sampling Equipment}

The sampler is pictured in Figure 1. The Gas Vapor Probe was designed specifically to sample soil gases, but we have found it to be extremely useful for ground water sampling. The system has two different options for collecting samples: (1) a Retract-a-Tip sampling system that can be used to collect multiple depths with a single installation and is recovered after deployment and (2) a Gas Vapor Probe System Dedicated Tip that is deployed for long-term sampling at a unique depth and cannot be recovered. The Dedicated Tips have a screen length of 0.900 inches, compared with 2.55 inches for the Retract-a-Tip; therefore, they have the capability of sampling at higher resolution. This paper will focus on the description of the Retract-a-Tip sampler, as it is the most useful for detailed characterization of a coastal aquifer.

There are several key components that are required to make this system useful for ground water sampling. The shielded-screen sampler used in this study consists of a hollow, 304-grade stainless steel center stem that is covered

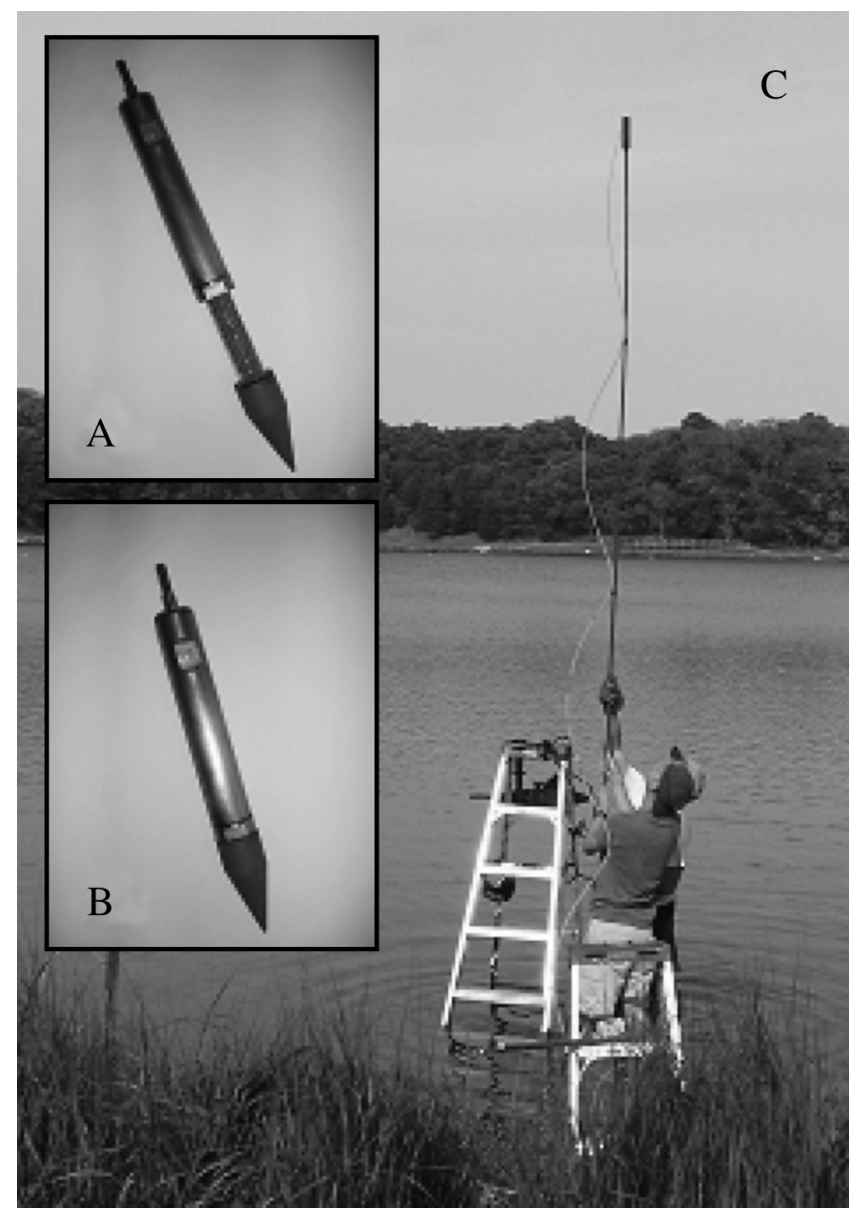

Figure 1. The AMS Retract-a-Tip sampler (A) screen exposed, (B) screen shielded and (C) in use during field sampling. 
with a stainless steel, 50- $\times$ 50-mesh screen (Figure 1). The center stem is terminated by a hardened stainless steel tip and shielded by a retractable stainless steel cover. The sampler must be fully disassembled for cleaning and replacement of screens. Its movable parts give the user the ability to open and close the screened interval portion of the sampler (Figures 1A and 1B). The sampler threads directly to hollow steel extension rods. The pressure of driving or even pushing the probe into the subsurface prevents the screened interval from opening and becoming clogged with sediment.

At the desired depth of sampling, the top of the extension rod is lifted either manually or with a jack to expose the screen. The screened interval of the center stem is connected to the surface by a $4.8-\mathrm{mm}$ ID $\times 6.8-\mathrm{mm}$ OD section of nylon or Teflon tubing that runs through the hollow core of the extension rods. The OD of the nylon tubing is small enough to slide easily inside the $1.0-\times 0.625-\mathrm{ft}$ OD, hollow steel extension rods. We use a 50-feet $(\sim 16 \mathrm{~m})$ roll of tubing, which would represent an upper-limit sampling depth. The sampler threads directly to the steel rods and can be extended and driven to depths of $\sim 10 \mathrm{~m}$ and possibly deeper, depending on the geological characteristics of the aquifer.

The second component of the system is the extension drive adapter. The extension drive adapter is a bypass fitting that allows the steel rods to be driven into the ground without disconnecting or coupling the tubing that connects the sampler to the surface. The extension drive adapter also has a slotted impact surface for driving the sampling tip into the ground.

The sampler may be driven into the ground via a handpowered slide hammer or a hammer drill. The $5.0-\mathrm{kg}$ slide hammer (included with the kit) works well for most applications, though its major drawback is the strain on the user for long deployments. We chose to use a Bosch 11230EVS hammer drill powered by a Honda EU1000i 4-stroke gasoline generator. The hammer drill is rated at $120 \mathrm{~V} \mathrm{AC}$ and 50 to $60 \mathrm{~Hz}$, and it draws a maximum of $8.8 \mathrm{~A}$ at the highest setting. The generator, also rated at $120 \mathrm{~V}$ AC and $60 \mathrm{~Hz}$, provides a maximum of $7.5 \mathrm{~A}$. It is able to power the drill when the drill is set on low to intermediate settings, which we have found adequate for most applications.

\section{Sample Collection}

During field testing, ground water samples were drawn to the surface using a peristaltic pump. The nylon tubing was flushed with ground water at three equivalent volumes of the tubing space for each sample depth $(\sim 1500 \mathrm{~mL}$ for $10 \mathrm{~m}$ of tubing). Sampling rates generally ranged from 20 to $500 \mathrm{~mL} /$ min depending on the sediment characteristics at the screened interval. Salinity, temperature, dissolved oxygen (D.O.), $\mathrm{pH}$, and oxidation reduction potential were measured using a YSI ${ }^{\mathrm{TM}}$ 600XLM multiparameter sonde. A flowthrough cell was used to determine when water properties had stabilized so that field data could be recorded and samples for laboratory analysis could be collected.

After the YSI measurements were recorded, the flowthrough cell was disconnected and samples were filtered through a $0.45-\mu \mathrm{m}$ Pall, AquaPrep ${ }^{\mathrm{TM}} 600$ inline filter capsule and collected in several types of sample bottles. We found this relatively low-cost capsule filter to have excellent blanks for nutrients and many trace metals, and long life often under extreme loading with fine-grained particles that may pass the sampler screen. Samples were collected for nutrients $\left(\mathrm{NO}_{3}^{-}, \mathrm{NH}_{4}^{+}, \mathrm{PO}_{4}^{3-}, \mathrm{SiO}_{4}^{-}\right)$, salinity, and trace metals $(\mathrm{Fe}, \mathrm{Mn}, \mathrm{Ba})$. Trace metal and $\mathrm{PO}_{4}{ }^{3-}$ samples were acidified to a $\mathrm{pH}$ of $<2$ with ultrapure $8 \mathrm{~N} \mathrm{HNO}_{3}$ (SeaStar), and nutrient samples were kept on ice until they could be transported to a $-20^{\circ} \mathrm{C}$ freezer at the laboratory (typically within $6 \mathrm{~h}$ of collection). Nutrient analyses were carried out using standard methods on a Lachat nutrient autoanalyzer (Zellweger Analytics, Quickchem ${ }^{\circledR} 8000$ Series), and trace metals were determined on a Finnegan Mat Element 2 ICP-MS.

\section{Assessment}

Though we have successfully used the sampler for collecting ground water in a variety of coastal settings, here we present results from two hydrogeologically contrasting environments influenced by submarine ground water discharge: Waquoit Bay, Massachusetts, and Ubatuba, Brazil. These examples were chosen to illustrate the importance of obtaining high-resolution samples in coastal aquifers. We selected elements and water quality parameters that are known to exhibit nonconservative behavior during fresh-salty ground water interaction.

In Waquoit Bay, the sampler was driven to $\sim 5.5 \mathrm{~m}$ and included 16 samples that were spaced at $45-\mathrm{cm}$ intervals, except at the interface between fresh and saline ground water, where samples were spaced by $15 \mathrm{~cm}$. This approach provides enhanced sampling detail where chemical gradients were likely to be most significant. The saline transition zone ( 0 to 25 ) occurred in a very narrow interval between $\sim 2$ and $3 \mathrm{~m}$ (Figure 2). D.O. generally decreased with depth, with two subsurface maxima at 1.52 and $3.35 \mathrm{~m}$. The shallowest subsurface D.O. peak was observed at a similar depth in other profiles collected at this site; therefore, it is likely a real feature.

Nitrate generally decreased with depth and was near the detection limit at the first sign of a salinity increase (Figure 2). This pattern suggests that denitrification is rapid upon mixing between fresh and salty ground water. Ammonium was highly correlated with salinity $\left(R^{2}=0.9611\right)$, suggesting conservative mixing between a high-salinity endmember $(\sim 40 \mu \mathrm{M})$ and a fresh water endmember (below detection limit). Reduction of organic matter in the relatively organicrich surface sediments of the bay is the likely source of the high $\mathrm{NH}_{4}^{+}$(Talbot et al. 2003; Charette et al. 2005). Phosphate also increased with increasing salinity but displayed a broad subsurface minimum between 0.6 and $2.0 \mathrm{~m}$. As this occurred in the low dissolved Fe region, this decrease could be indicative of scavenging onto $\mathrm{Fe}$ (hydr)oxides (Figure 2; Charette and Sholkovitz 2002). Like ammonium, silicate increased with increasing salinity, suggesting enhanced weathering of amorphous silica in the high-salinity region of the subterranean estuary (Miretzky et al. 2001).

$\mathrm{Fe}$ and $\mathrm{Mn}$ distributions indicate that an active redox cycle is at work in the subterranean estuary (Figure 2). 

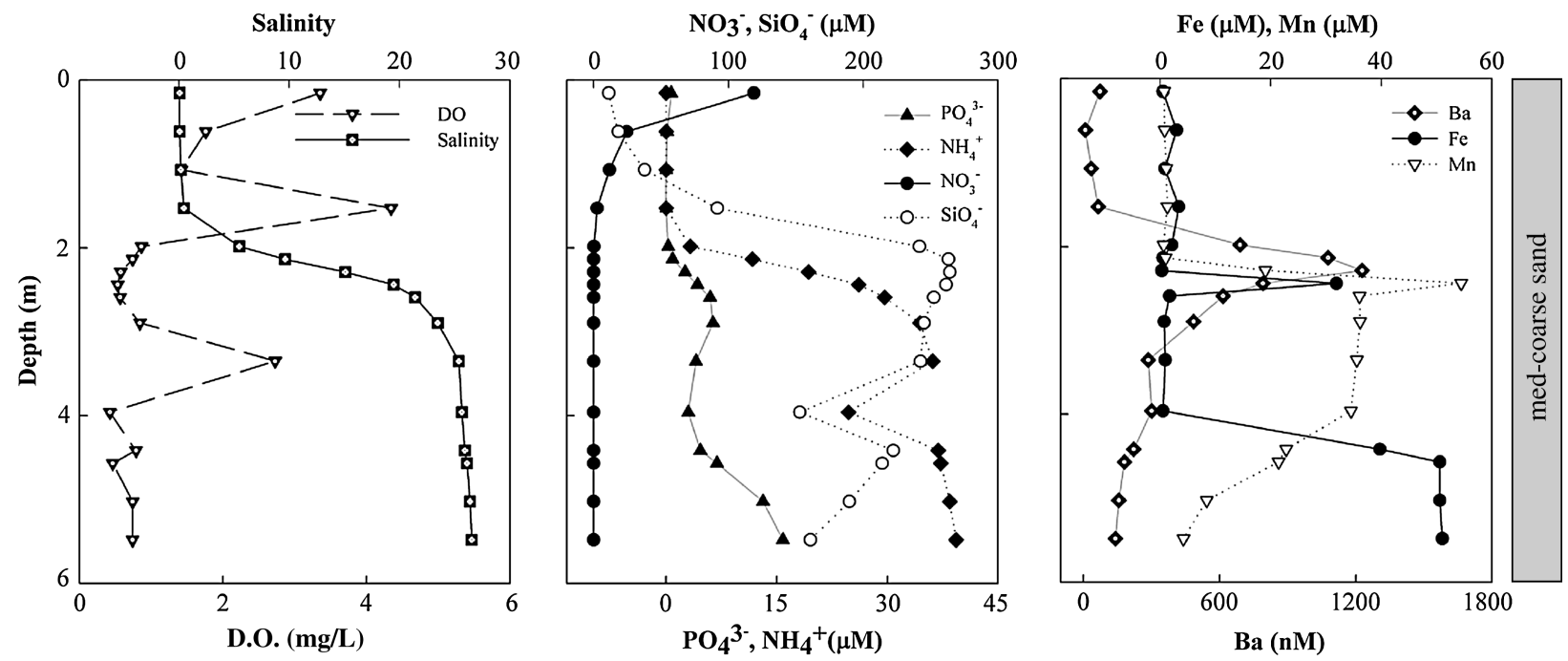

Figure 2. Ground water profile at Waquoit Bay, Massachusetts.

The brackish to high-salinity zones of the subterranean estuary were zones of high dissolved $\mathrm{Mn}$ and $\mathrm{Fe}$, respectively. Froelich et al. (1979) noted that reduction of nitrate, $\mathrm{Mn}$ oxides, and $\mathrm{Fe}$ oxides, in order of decreasing energy obtained per molecule of organic matter reduced, occurs in suboxic environments within fine-grained, organic-rich sediments. Despite the scale of the ground water profile and the permeable nature of the aquifer sediments, the chemical distributions at this location are identical to those observed by Froelich et al. (1979) and many others since (1) nitrate decreases due to denitrification; (2) Mn increases due to reduction of $\mathrm{Mn}$ oxides; and (3) $\mathrm{Fe}$ increases due to $\mathrm{Fe}$ oxyhydroxide reduction. Our conclusion from the Waquoit Bay study is that high-resolution ground water sampling is absolutely necessary in resolving such patterns.

Barium was, on average, 1 to 2 orders of magnitude enriched in the subterranean estuary over surface water, consistent with recent studies suggesting that ground water is a major source of Ba to the ocean (Moore 1997; Shaw et al. 1998). While Waquoit Bay surface water $\mathrm{Ba}$ is $\sim 50$ $\mathrm{nM}$, the maximum $\mathrm{Ba}$ concentration at this location was $1200 \mathrm{nM}$ (Figure 2). As indicated by its relationship with salinity, $\mathrm{Ba}$ behaves nonconservatively during ground water-sea water mixing, with a large-scale release of $\mathrm{Ba}$ in the mid-salinity zone of this subterranean estuary, consistent with the Ba release in many surface estuaries (Coffey et al. 1997).

In Flamengo Bay, Ubatuba, Brazil, we collected a ground water profile in the sediments beneath the head of the bay. The surficial sediments $(0$ to $0.4 \mathrm{~m})$ were extremely coarse grained, with ground water salinity similar to that of the overlying water column (Figure 3). At $\sim 0.4 \mathrm{~m}$, there was a sharp transition from the well-sorted coarse sands to poorly sorted sands, silts, and clays, which also corresponded to a sharp decrease in salinity. The decrease in sediment permeability and a likely increase in hydraulic head are possible explanations for this "inverse" subterranean estuary: denser saline ground water overlying less dense fresh ground water. As would be expected, $\mathrm{pH}$ decreased with decreasing salinity through the profile. Silicate was highly enriched in the ground water relative to surface water, ranging from 30 to $120 \mu \mathrm{M}$ and increasing across the saline-fresh ground water interface. Though our sediment core did not penetrate the entire depth of our ground water profile, our bottom two samples were collected from a zone of highly weathered bedrock, which, combined with our results from Waquoit Bay, demonstrates that the system is useful for collecting ground water from a diverse range of aquifer substrates.

\section{Discussion}

In the Waquoit Bay field tests, the sampler provided discrete samples from $\sim 16$ to 20 unique depths in each probehole, an average sample resolution of $30 \mathrm{~cm}$. We have also been able to increase the sampling resolution to

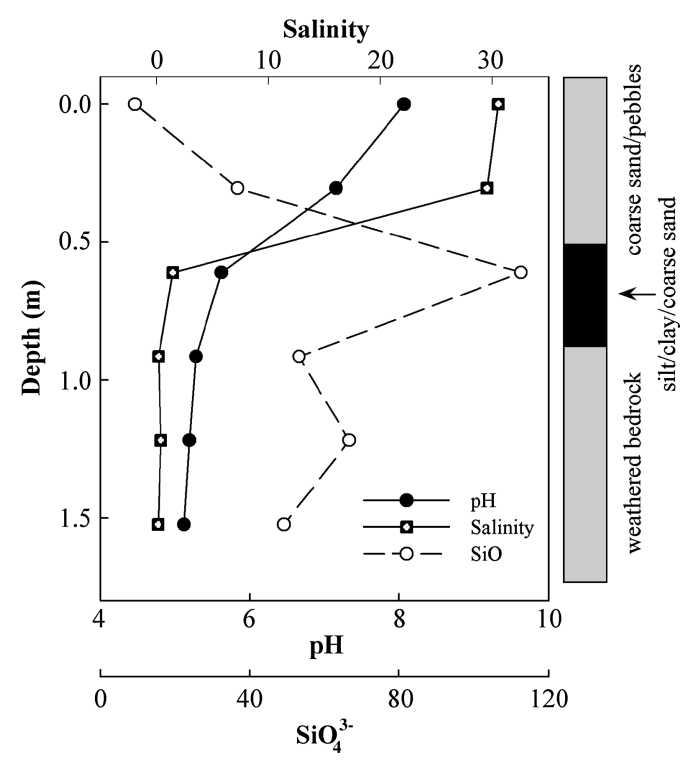

Figure 3. Ground water profile at Ubatuba, Brazil. 
$10 \mathrm{~cm}$ when needing to resolve microscale interfaces. This resolution would be time consuming, expensive, and most likely impossible to achieve with a conventionally installed multilevel screened well.

Another key advantage of using this system is that there is the option of changing the sampling depth or protocol to suit the evolving geochemical profile of each individual probehole. This aspect of the sampler is hardly possible when using a conventional monitoring well, but certainly possible with an exposed-screen well-point system. However, exposed-screen systems are prone to sample contamination and clogging of the screen during long deployments. Together, the shielded screen and internal tubing of the system prevent sample contamination by mixing with water from previous sample intervals, or the contamination from the inside of steel extension rods.

A major limitation of the sampler is the maximum depth of penetration; we have tested the system to $10 \mathrm{~m}$, but given ideal conditions, it may be possible to probe deeper. This presumes that the water table (or head in the well) is $<10 \mathrm{~m}$ below the ground surface, as a peristaltic pump will not work beyond a lift any greater than this. Another limitation, when compared with conventional monitoring well installation, is that it cannot penetrate bedrock or (most likely) a confining layer. Last, the sampler is best suited for sandy, permeable sediments, though we have had some success with deployments in fine-grained sediments. In such environments, clogging and slow-flow rates become more of an issue.

The sampler has been a vast improvement over any other methods we have attempted to date. It solves many of the problems associated with sampling from monitoring wells and traditional exposed-screen well points, with the major advantage being the increase in sampling resolution that has helped us to unravel geochemical processes in the subterranean estuary. Finally, it is easy to set up and use (see the Comments and Recommendations section for further details), and is a cost effective and durable sampler that will help to improve our understanding of ground water-surface water biogeochemical interactions in many different hydrogeologic settings. Enhancing the resolution of data and our knowledge of these in lakes, rivers, and coastal zones can give us better estimates of global chemical budgets and will ensure that we make the proper decisions about managing water resources in the future.

\section{Comments and Recommendations}

There are a few tips and suggestions that are very helpful to the beginning user. In the past 2 years, we have tested several different kinds of tubing with the system. A roll of Teflon tubing comes with the Gas Vapor Probe kit purchased directly from manufacturer. The Teflon tubing performs very well under field conditions but is prone to kinking and is more expensive if sampling methods do not require it. As an alternative, we have had much success with 4.8-mm ID $\times$ 6.4-mm OD nylon tubing, made by Mazzer Industries, which proved to be a strong and durable alternative to Teflon. It less expensive than Teflon and is also nearly impervious to kinking or breaking.
The 4130 Alloy steel extension rods of the Vapor Probe will begin to rust as soon as you receive them from the manufacturer. Rinsing with fresh water and drying will minimize the amount of rust. When rust does develop on the inside of the extension rods, it may be difficult to thread the nylon tubing inside and also may introduce contamination into the tubing. A 0.25 -inch piece of stainless steel tubing works well to remove any rust from the center of the extension rods before threading the tubing. When collecting samples for low-level trace metal analysis, we usually use 304-grade stainless steel extension rods, which are available from most industrial metal companies. However, one drawback to the stainless steel is that it is soft and prone to bending when using the supplied jack to recover the system from depth. Extracting a system using a large tripod and winch may reduce the tendency of the steel to bend.

The threading on the 4130 steel extension rods becomes worn with rust and general field wear and tear. To minimize this, keep exposed threads from dragging on the ground or becoming clogged with sediment. When connecting extension rods with coupling nuts, it is a good idea to tighten them with an adjustable wrench and a pair of vice grips. This keeps the threads from moving inside of the coupling nut and becoming worn. This is especially important with the stainless steel extension rods, due to their softer nature. It is also a good idea to cover the threads of the extension rods with plastic end caps when they are not being used, so there is no chance of damage.

During sampling, we recommend reversing the flow of the pump to flush any sediment off the screened interval before closing the sampler. It is also helpful to flush the screen prior to opening the screen at a new sampling depth. Sometimes the screen will become wedged inside of the steel sleeve and the well point has to be removed from the ground and manually cleaned. At this point, the condition of the screen should be evaluated, and replaced if necessary. Often, a jagged screen can cause the tip to bind inside the sleeve.

Last, several safety precautions should be observed when using the system. Safety glasses should be worn at all times as sand and other debris can become airborne while the system is being installed with the hammer drill. Also, the hammer drill and all other A/C-powered equipment should be plugged into a ground-fault interrupter when being used over water.

\section{Acknowledgments}

We would like to extend our thanks to Jeremy Testa, Adam Rago, Kevin Kroeger, Ed Sholkovitz, and Craig Herbold for assistance in the field and laboratory. We thank the director and staff of the Waquoit Bay National Estuarine Research Reserve for the use of their facilities during our field testing of the system. Trace metal analyses were performed by Dave Schneider and Lary Ball of the WHOI ICP-MS Facility. Travel support for the Brazil SGD Intercalibration Experiment was provided by Bill Burnett through a grant from the Intergovernmental Oceanographic Commission. Ed Sholkovitz, Paul Johnson, and one anonymous reviewer provided comments that greatly improved 
the manuscript. Funding for the purchase and testing of this equipment was provided by NSF Grant OCE-0095384 to M.A.C.

Editor's Note: The use of brand names in peerreviewed papers is for identification purposes only and does not constitute endorsement by the authors, their employers, or the National Ground Water Association.

\section{References}

Abraham, D.R., M.A. Charette, M.C. Allen, A. Rago, and K.D. Kroeger. 2003. Radiochemical estimates of submarine groundwater discharge to Waquoit Bay, Massachusetts. Biological Bulletin 205: 246-247.

Barcelona, M.J., J.P. Gibb, and R.A. Miller. 1983. A guide to the selection of materials for monitoring well construction and ground-water sampling. Illinois State Water Survey Contract Report 327. Champaign, Illinois: Department of Energy and Natural Resources.

Barlow, P.M. 2003. Ground water in freshwater-saltwater environments of the Atlantic coast. USGS Circular 1262. U.S. Geological Survey.

Cambareri, T.C., and E.M. Eichner. 1998. Watershed delineation and ground water discharge to a coastal embayment. Ground Water 36, no. 4: 626-634.

Charette, M.A., E.R. Sholkovitz, and C. Hansel. 2005. Trace element cycling in a subterranean estuary: Part 1 . Geochemistry of the permeable sediments. Geochimica et Cosmochimica Acta 69, no. 8: 2095-2109.

Charette, M.A., and E.R. Sholkovitz. 2002. Oxidative precipitation of groundwater-derived ferrous iron in the subterranean estuary of a coastal bay. Geophysical Research Letters 29, no. 10: 1-4.

Coffey, M., F. Dehairs, O. Collette, G. Luther, T. Church, and T. Jickells. 1997. The behaviour of dissolved barium in estuaries. Estuarine, Coastal and Shelf Science 45, no. 1: 113-121.

E.C. Jordan Inc. 1990. Installation Restoration Program, Phase I of the Ashumet Valley Ground Water Study, v. I and v. II. Massachusetts Military Reservation, Cape Cod, Massachusetts: E.C. Jordan.

Froelich, P.N., G.P. Klinkhammer, M.L. Bender, N.A. Luedtke, G.R. Heath, D. Cullen, P. Dauphin, D. Hammond, B. Hartman, and V. Maynard. 1979. Early oxidation of organic matter in pelagic sediments of the eastern equatorial Atlantic: Suboxic diagenesis. Geochimica et Cosmochimica Acta 43, no. 7: 1075-1090.

Geoprobe Systems. 2001. Vertical profiling made easy with Geoprobe's groundwater profiler, Product Bulletin No. PBGP0701: Groundwater Profiler. Kejr, Salina, Kansas: Geoprobe Systems.

Johannes, R.E. 1980. The ecological significance of the submarine discharge of groundwater. Marine Ecology 3, no. 44: 365-373.

R.J. Stanley. 1990. Technical Report WHOI-90-35, Woods Hole Oceanographic Institution.

LeBlanc, D.R., J.H. Guswa, M.H. Frimpter, and C.J. Londquist. 1986. Ground-Water Resources of Cape Cod, Massachusetts: Cape Cod Commission. Barnstable, Massachusetts.

Mahiques, M.M. 1995. Sedimentary dynamics of the bays off Ubatuba, State of São Paulo. Boletim do Instituto Oceanográfico, São Paulo 43, no. 2: 111-122.

Miretzky, P., V. Conzonno, and A. Fernández Cirelli. 2001. Geochemical processes controlling silica concentrations in groundwaters of the Salado River drainage basin, Argentina. Journal of Geochemical Exploration 73, no. 3: 155-166.
Moore, W.S. 1999. The subterranean estuary: A reaction zone of ground water and sea water. Marine Chemistry 65, no. 1-2: 111-125.

Moore, W.S. 1997. High fluxes of radium and barium from the mouth of the Ganges-Brahmaputra River during low river discharge suggest a large groundwater source. Earth and Planetary Science Letters 150, no. 1-2: 141-150.

Oldale, R.N. 1982. Pleistocene stratigraphy of Nantucket, Martha's Vinyard, the Elizabeth Islands, and Cape Cod, Massachusetts, In Late Wisconsinan Glaciation of New England, ed. G.J. Larson and B.D. Stone. Dubuque, Iowa: Kendall/Hunt. $34 \mathrm{pp}$.

Oldale, R.N. 1976. Notes on the generalized geologic map of Cape Cod. USGS Open-File Report 76-765. U.S. Geological Survey.

Oliveira, J., W.C. Burnett, B.P. Mazzilli, E.S. Braga, L.A. Farias, J. Christoff, and V.V. Furtado. 2003. Reconnaissance of submarine groundwater discharge at the Ubatuba coast, Brazil, using ${ }^{222} \mathrm{Rn}$ as a natural tracer. Journal of Environmental Radioactivity 69, no. 1-2: 37-52.

Puls, R.W., and C.J. Paul. 1997. Multi-layer sampling in conventional monitoring wells for improved estimation of vertical contaminant distributions and mass. Journal of Contaminant Hydrology 25, no. 1-2: 85-111.

Ronen, D., M. Magaritz, and I. Levy. 1987. An in-situ multilevel sampler for preventative monitoring and study for hydrochemical profiles in aquifers. Ground Water Monitoring and Remediation 7, no. 4: 69-74.

Schulmeister, M.K., J.M. Healey, J.J. Butler Jr., and G.W. McCall. 2004. Direct-push geochemical profiling for assessment of inorganic chemical heterogeneity in aquifers. Journal of Contaminant Hydrology 69, no. 3-4: 215-232.

Shaw, T.J., W.S. Moore, J. Kloepfer, and M.A. Sochaski. 1998. The flux of barium to the coastal waters of the southeastern USA: The importance of submarine groundwater discharge. Geochimica et Cosmochimica Acta 62, no. 18: 3047-3054.

Talbot, J.M., K.D. Kroeger, A. Rago, M.C. Allen, and M.A. Charette. 2003. Nitrogen flux and speciation through the subterranean estuary of Waquoit Bay, Massachusetts. Biological Bulletin 205: 244-245.

Testa, J.M., M.A. Charette, E.R. Sholkovitz, M.C. Allen, A. Rago, and C.W. Herbold. 2002. Dissolved iron cycling in the subterranean estuary of a coastal bay: Waquoit Bay, Massachusetts. Biological Bulletin 203: 255-256.

Valiela, I., K. Foreman, M. LaMontagne, D. Hersh, J. Costa, P. Peckol, B. DeMeo-Anderson, C. D'Avanzo, M. Babione, C.H. Sham, J. Brawley, and K. Lajtha. 1992. Couplings of watersheds and coastal waters: Sources and consequences of nutrient enrichment in Waquoit Bay, Massachusetts. Estuaries 15, no. 4: 443-457.

Zemo, D.A., T.A. Delfino, J.D. Gallinatti, V.A. Baker, and L.R. Hilpert. 1995. Field comparison of analytical results from discrete-depth ground water samplers. Ground Water Monitoring and Remediation 15, no. 1: 133-141.

Zemo, D.A., Y.G. Pierce, and J.D. Gallinatti. 1994. Cone penetrometer testing and discrete-depth groundwater sampling techniques: A cost effective method of site characterization in a multiple-aquifer setting. Ground Water Monitoring and Remediation 14, no. 4: 176-182.

\section{Biographical Sketches}

Matthew A. Charette, corresponding author, received a B.S. in oceanography from the Florida Institute of Technology and 
a Ph.D. in chemical oceanography from the University of Rhode Island. He is currently an associate scientist at the Woods Hole Oceanographic Institution in the Department of Marine Chemistry and Geochemistry, 266 Woods Hole Road, Woods Hole, MA 02543; (508) 289-3205; fax (508) 457-2193; mcharette@whoi.edu.
Matt C. Allen, received a B.S. in geology from North Carolina State University and a M.S. degree in geology from East Carolina University. He is currently a professional geologist at ENSR Consulting and Engineering, 7041 Old Wake Forest Road, Raleigh, NC 27616; (508) 289-3205, fax (508) 457-2193; mcallen@ensr.aecom.com.

\section{gatonal water 2006 NGWA Ground Water and Environmental Law Conference}

July 6-7, 2006

Holiday Inn Chicago Mart Plaza Hotel • Chicago, Illinois

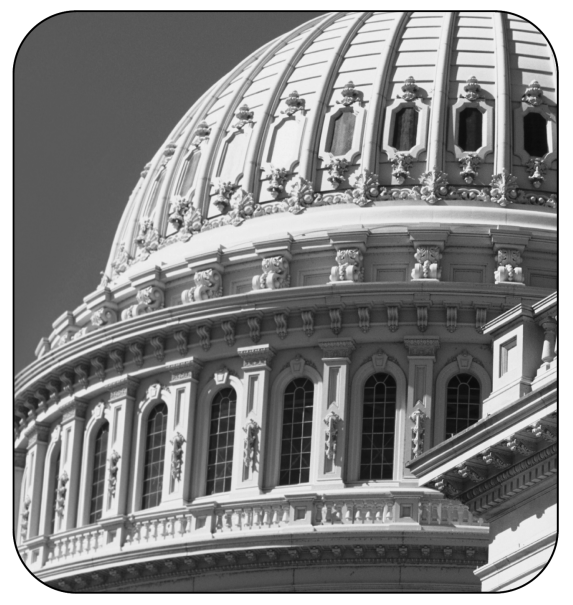

This conference will feature papers on ground water law and environmental contamination litigation, presentations on specific court cases, and presentations of hydrogeology, contaminant transport, and modeling in the courtroom. Major topics will include:

- Water law: New regulations

- Coal bed methane development: Legal implications

- Science in the courtroom: Data visualization

- Ethics for attorneys and expert witnesses

- Uncertainty and defensibility in modeling

- Transboundary water disputes

- Emerging contaminants

Attendees will participate in a mock trial as jurors. Electronic copies of all submitted manuscripts will be available to paid registrants.

\section{For complete information, go to http://www.ngwa.org/e/conf/0607065066.cfm.}

